\title{
Levels of Trace Elements in Hydatid Cyst Fluid : Analytical Study
}

\author{
Dr. Amal KH. Khalaf* \& Dr. Muslim K. Kadeem** \\ *Microbiology Dept., Cancer Research Unit \Coll. of Medicine \Thi-Qar University \\ ** Surgery Dept. $\backslash$ College of Medicine $\backslash$ Thi-Qar University \\ Aml-kh@utq.edu.iq*, muslim@utq.edu.iq**
}

\begin{abstract}
:
The aim of the following study was to estimate the levels of trace elements in hydatid cyst fluid and evaluation the role of this elements on parasite life . trace elements in the fluid of hydatid cyst were detected by atomic absorption spectroscopy which found high ratio of $\mathrm{Ca}, \mathrm{K}, \mathrm{Fe}, \mathrm{Mg}, \mathrm{Mn}, \mathrm{Na}, \mathrm{Cu}$, and $\mathrm{Zn}$ while $\mathrm{P}, \mathrm{Cr}, \mathrm{Co}, \mathrm{Cd}$, $\mathrm{Pb}$, and $\mathrm{Ni}$ were low and include $(8.71,9.55,15.36,5.91,9.2$, and $11.3 \backslash \mu \mathrm{g}$ ) respectively .
\end{abstract}

Key words : Hydatid fluid, Trace elements, atomic absorption spectra

\section{Introduction :}

The disease of hydatid cyst is the proliferation of parasite in tissue by the different species of the genus Echinococcus, and represents a world health problem with important conomic implications (King et al., 2000). Hydatid disease is common witht significant parasitic disease in endemic areas like Iraq. (Polat and Atamanalp , 2009). Hydatid cyst may develop in any organ of the human body, most frequently in the liver (60$70 \%$ ) and the lungs (20-30\%) (Bavbek et al., 2000). The size, number and location of cyst are determine the symptoms in patients. it is still asymptomatic until the cysts become large enough to damage adjacent tissues and organs, they are usually asymptomatic Clinical symptoms will not occur until the cyst ruptures because of trauma or affects neighboring structures. Secondary cyst or spillage of fluid from damage of hydatid cyst which is occur because of minor trauma, followed by an allergic reaction characterized by urticaria; more seriously, there may be an anaphylactic reaction (Polat and Atamanalp , 2009).

The aim of present study is to estimate the levels of trace elements in the fluid of hydatid cyst in patients with hydatidosis and to explain the role of these metals for the parasite life. 


\section{Materials \& Methods :}

Fresh hydatid cyst were obtained from liver patients that were surgically removed in Al- Hussain Teaching Hospital in Nassiriyah city. They were wrapped carefully in clean plastic bags, placed in an ice box, and bring to the microbiology lab of medical college, where the fluid of hydatid cyst removed according to Smyth (1964) method .

Hydatid cyst fluids were collected by $5 \mathrm{ml}$ needle volume and provided to atomic

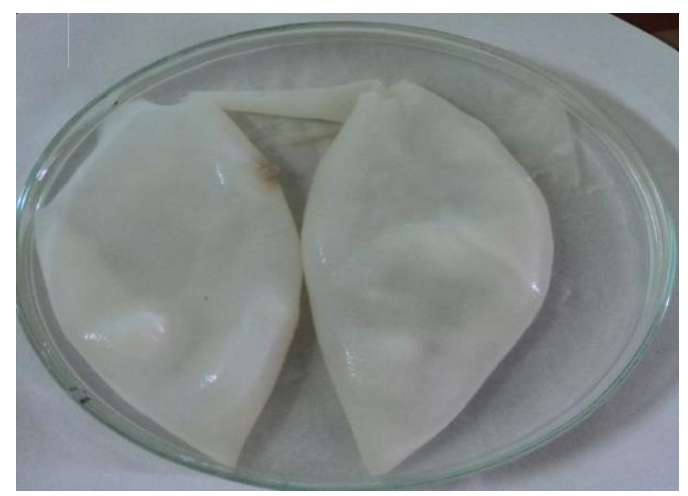

(A) absorption examination . the fluid of hydatid cyst were mixed $(0.5-3 \mathrm{ml})$ with in an equal volume of acid digestion mixture (perchloric acid and nitric acid) in $10 \mathrm{ml}$ plastic tube. Shaking the sample enhanced the rate of digestion in one minute only. The digestion was completed in an oven at $37^{\circ} \mathrm{C}$ for 48 hours and finally a clear solution was formed which was diluted by 1:10 $\mathrm{ml}$ by deionized water and prepared for atomic absorption ( Mehdi et al. 2010).

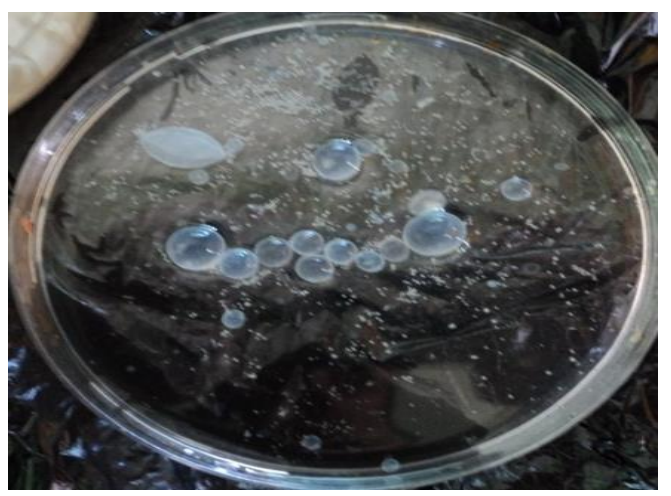

(B)

\section{Hydatid cyst :(A) laminated layer (B) hydatid cyst fluid}

\section{Results and Discussion :}

The essential components of biological structures of organisms is the organic metal or trace elements, but it may be toxic at concentrations beyond those necessary for their biological functions. This metal is effective at very low concentrations, and their concentration in the fluids must be tightly regulated, deficiency or excess both can killed the organisms ( De Olivier etal., 2001 and Shaeffer, 2006).

The following study investigates high levels of this material in the fluid of hydatid cyst of patients with hydatidosis . trace elements in the fluid of hydatid cyst included $\mathrm{Cd}, \mathrm{Ni}, \mathrm{Na}$, $\mathrm{Ca}, \mathrm{Cu}, \mathrm{Fe}, \mathrm{Mg}, \mathrm{Mn}, \mathrm{Co}, \mathrm{Cr}, \mathrm{Pb}, \mathrm{Zn}$ , $\mathrm{K}$ and $\mathrm{P}$. 


\section{Email:utjmed@utq.edu.iq}

$\mathrm{Ca}, \mathrm{Fe}, \mathrm{Mg}, \mathrm{Cu}, \mathrm{Na}, \mathrm{Zn}, \mathrm{Mn}$ and $\mathrm{K}$ were recorded in a high levels within the basic component of the fluid of hydatid cyst while $\mathrm{Cd}, \mathrm{Ni}, \mathrm{Co}, \mathrm{Cr}, \mathrm{Pb}$ and $\mathrm{P}$ were found in low concentration when compared with the previous one.

The following table explain the concentration of the main minerals that consist a part of the fluids of hydatid cyst where Fe has 95.35, Zn (86.56 । $\mu \mathrm{g}), \mathrm{Cu}(60.77 \backslash \mu \mathrm{g}), \mathrm{Ca}(70.21 \backslash \mu \mathrm{g})$, $\mathrm{Mg}(61.4 \backslash \mu \mathrm{g}), \mathrm{Mn}(29.82 \backslash \mu \mathrm{g})$, $\mathrm{K}(36.82 \backslash \mu \mathrm{g})$ and $\mathrm{Na}(49.22 \backslash \mu \mathrm{g})$ while $\mathrm{Co}, \mathrm{Cr}, \mathrm{Pb}, \mathrm{P}, \mathrm{Cd}$, and $\mathrm{Ni}$ were reported ( $15.36,9.55,9.2,8.71,5.91$, and $1.3 \backslash \mu \mathrm{g}$ ) respectively.

Trace elements have biological activities strongly associated with the biological systems; proteins are mostly bound to these metals , forming metalloproteins. They are consist part of enzymatic systems as metalloproteins, have structural and storage functions, or join to the protein to be transported to their target site in the organism (Srivastav et al.2011).

The Fe content in fluid of hydatid cyst is higher than the other trace elements and similar to that result found in content of Fasciolopsis buski body which is achieved by Srivastav et al.(2011) . Iron is an important element which takes part in biochemical processes acting as catalyst or cofactors because iron was found as inorganic deposits in the intestinal cells of many helminthes (Fraga 2005) .

Hydatid cyst fluids were also contain $\mathrm{Zn}$ in high level . The highest value of $\mathrm{Zn}$ consist the basic contents in several parasites e.g. Fasciolopsis buski , Fischoederius elongatus, Gastrodiscoides hominis,
Web Site: https://imed.utq.edu.iq

Fischoederius cobboldi, Gastrothylax crumenifer, and Orthocoelium orthocoelium. Zinc is required for the started of DNA and protein synthesis, within the cell (Fraga ,2005). The availability of Zinc within nucleolus leads to increase mRNA synthesis and this in turn causes increased availability of enzymes for DNA synthesis or transcription of DNA into RNA (Fraga ,2005 and Srivastav et al.2011) .

$\mathrm{Ca}, \mathrm{K}, \mathrm{Na}$ and $\mathrm{Cu}$ likes $\mathrm{Fe}$ and $\mathrm{Zn}$ showed high values in fluids of hydatid cyst which are needed for the development of connective tissue, nerve coverings, and bone. $\mathrm{Ca}, \mathrm{K}, \mathrm{Na}$, and $\mathrm{Cu}$ acts as a reductant in the enzymes superoxide dismutase, cytochrome oxidase, lysil oxidase, dopamine hydroxylase, and several other oxidases that reduce molecular oxygen (Aggett, 1994 and Ozen etal., 2009). The same results were also found in Fischoederius cobboldi, Gastrothylax crumenifer, and Orthocoelium orthocoelium parasites but lowest in Fischoederius elongatus, Gastrodiscoides hominis (Srivastav etal.2011).

all forms of life required Manganese and Magnesium as an essential trace nutrient and the best known manganese-containing polypeptides may be arginase, the diphtheria toxin, and Mn-containing superoxide dismutase (Mn-SOD) . Mn which is essential in the synthesis of glycoproteins, polysaccharides and sterol. The higher amounts of $\mathrm{Mg}$ suggests that it is essential for "Intercellular ionic bridging" changes 


\section{Email:utjmed@utq.edu.iq}

at the cell surface and shape of the cell during cleavage ( Tandon and Ray, 1994) and (Ozen et al., 2009).

In Comparison with the previous elements ; $\mathrm{Ni}, \mathrm{Co}, \mathrm{Cr}, \mathrm{Pb}, \mathrm{P}$, and $\mathrm{Cd}$ were lowest which have been found in poor amounts in the fluid of hydatid cyst and similar to that found in some trematoda. Chromium is important for the structure and metabolism of nucleic acids and difficiency leads to several dysfunctions. Ni can influence the activity of numerous enzymes in vitro, An enzymes have been estimated to be activated or inhibited by $\mathrm{Ni}$. $\mathrm{Cd}$ and $\mathrm{Pb}$ are more important on the body's organ
Web Site: https://imed.utq.edu.iq

systems, like the nervous system, but also the bones, the kidneys, and the cardiovascular, immune, and reproductive systems . Presence of $\mathrm{Cd}$ in small amounts in the fluid of hydatid cyst and among all the flukes : Fasciolopsis buski, Fischoederius elongatus, Gastrodiscoides hominis, Fischoederius cobboldi, Gastrothylax crumenifer, and Orthocoelium orthocoelium, is known to be very toxic to man as it accumulates in kidneys and also affects the reproductive organs ( Tandon and Ray , 1994 ; De Olivier et al., 2001 and Srivastav et al.,2011) .

Table (1) :

The Pure Concentration of Trace elements of Hydatid Cyst Fluids

\begin{tabular}{|c|c|}
\hline Trace element & Concentration in hydatid cyst fluid ( $\mu \mathrm{g})$ \\
\hline $\mathbf{Z n}$ & 86.56 \\
\hline $\mathrm{Cu}$ & 60.77 \\
\hline $\mathrm{Fe}$ & 95.35 \\
\hline $\mathbf{C a}$ & 70.21 \\
\hline Mg & 61.4 \\
\hline Mn & 29.82 \\
\hline Co & 15.36 \\
\hline $\mathrm{Cr}$ & 9.55 \\
\hline $\mathbf{P b}$ & 9.2 \\
\hline $\mathbf{P}$ & 8.71 \\
\hline Cd & 5.91 \\
\hline K & $36 . .82$ \\
\hline $\mathrm{Na}$ & 49.22 \\
\hline $\mathbf{N i}$ & 1.3 \\
\hline
\end{tabular}

\section{Conclusions :}

1- Many type of trace elements were found in hydatid cyst .

2- Trace elements consist basic content in parasite life.

\section{Recommendations :}

1- Detection of trace elements in sera of patients. 


\section{Email:utjmed@utq.edu.iq}

2- Explain the effect of decrease or increase trace elements levels in sera of patients.

\section{References :}

- Aggett, P.J. (1994). Aspects of neonatal metabolism of trace metals. Acta Paediater Supp, 402: 75-82.

- Bavbek M, Caner H, and Erdoan B. (2000). Central nervous system hydatitosis in Turkey: a cooperative study and literature survey analysis of 458 cases. J Neurosurg; 93: 1-8.

- De Oliveira, F.S.; Viana, M.R. and Antonio, A.R. (2001). Differential effect of lead and zinc on inhibitory avoidance learning in mice. Braz J Med Biol Bes 34:117120.

- Fraga CG. (2005) - Relevance, essentiality and toxicity of trace elements in human health. Mol Aspects Med. 2005; 26(4-5): 23524.

- King, C. Cestodes, Mandel, GL, Bennet JE, and Dolin R (eds). (2000) Principles and practice of Infectious diseases 4th edn Churchill \& Livingstone, pp 29572965.

- Mahdi, J. ; Mohammad H. AlJawher; and Mahdi, N. K. (2010). Zinc and copper levels in hydatid cyst fluid and patient's blood . J. Pak. Med. Assoc. 60 (7) : 580-581.

- Mahdi NK, Al_Baldawi ,F.A. and , Benyan, A.K. (1996) .Immunoglobulin levels in sera and cyst fluid of human hydatidosis. Med. J. Basrah Univ. , 14: 91-9.

- Ozen N, Celik C, Ozkan K, Malazgirt Z, Isimer A, Sayal A. (2009) Trace elements in hydatid disease. J Trace Elem Electrolytes Health Dis 1992; 6: 67-70.

- Polat P, and Atamanalp SS. (2009) Hepatic hydatid disease: radiographics findings. EAJM;41:49-55.

- Shaeffer, G.L. (2006). Evaluation of basic zinc chloride as a zinc source for cattle. M.Sc thesis in North Carolina State University. Animal Science. Raleigh.

- Srivastav, S. K.; Murti, R. C. And Gupta Vinod, C . (2011). Quantitative Analysis of Trace Elements In Fasciolopsis buski and Gastrodiscoides hominis IJCPR,; 2(3):161-168.

- Tandon , V. and Ray, B. (1994). Analysis of trace element of some edible treamatodes parasitizing the bovine hosts . C. Science ; 67(7): 548-468. 


\section{مستويات العناصر النزرة في سائل الكيس العدري : دراسة تحليلية}

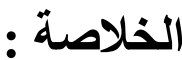

تهدف الدراسة الحالية الى تقدير مستوى العناصر النزرة في سائل الكيس العدري وتوضيح

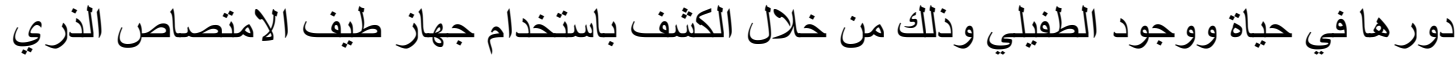
والتي وجدت نسبة عالية من العناصر النزرة ضمن سائل الكيس العدري مثل الكالسيوم

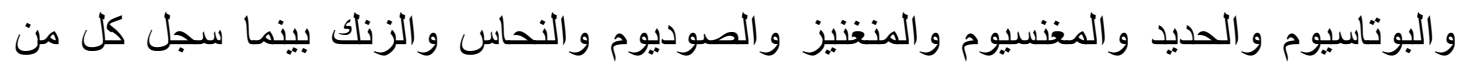

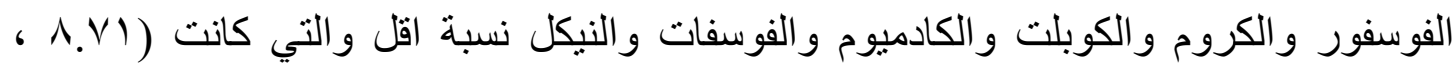
9.00 